\title{
REVIEW
}

Open Access

\section{Emerging concepts in the treatment of optic neuritis: mesenchymal stem cell-derived extracellular vesicles}

\author{
Anagha Aneesh ${ }^{1 \dagger}$, Alice Liu ${ }^{1 \dagger}$, Heather E. Moss², Douglas Feinstein' ${ }^{1}$, Sriram Ravindran³ ${ }^{3}$ Biji Mathew ${ }^{1 * \dagger}$ and
} Steven Roth ${ }^{1 *}$ (B)

\begin{abstract}
Background: Optic neuritis (ON) is frequently encountered in multiple sclerosis, neuromyelitis optica spectrum disorder, anti-myelin oligodendrocyte glycoprotein associated disease, and other systemic autoimmune disorders. The hallmarks are an abnormal optic nerve and inflammatory demyelination; episodes of optic neuritis tend to be recurrent, and particularly for neuromyelitis optica spectrum disorder, may result in permanent vision loss.

Main Body: Mesenchymal stem cell (MSC) therapy is a promising approach that results in remyelination, neuroprotection of axons, and has demonstrated success in clinical studies in other neuro-degenerative diseases and in animal models of ON. However, cell transplantation has significant disadvantages and complications. Cell-free approaches utilizing extracellular vesicles (EVs) produced by MSCs exhibit anti-inflammatory and neuroprotective effects in multiple animal models of neuro-degenerative diseases and in rodent models of multiple sclerosis (MS). EVs have potential to be an effective cell-free therapy in optic neuritis because of their anti-inflammatory and remyelination stimulating properties, ability to cross the blood brain barrier, and ability to be safely administered without immunosuppression.

Conclusion: We review the potential application of MSC EVs as an emerging treatment strategy for optic neuritis by reviewing studies in multiple sclerosis and related disorders, and in neurodegeneration, and discuss the challenges and potential rewards of clinical translation of EVs including cell targeting, carrying of therapeutic microRNAs, and prolonging delivery for treatment of optic neuritis.
\end{abstract}

Keywords: Anti-myelin oligodendrocyte glycoprotein associated disease, Autoimmune disorder, Exosome, Extracellular vesicles, MicroRNA, Multiple Sclerosis, Neurodegeneration, Neuromyelitis optica spectrum disorder, Optic neuritis, Optic nerve, Retina, Retinal ganglion cells, Stem cells

*Correspondence: bijim@uic.edu; rothgas@uic.edu

${ }^{\dagger}$ Joint first authors: Anagha Aneesh and Alice Liu

†oint Corresponding Authors: Biji Mathew and Steven Roth

${ }^{1}$ Department of Anesthesiology, College of Medicine, University

of Illinois, 835 South Wolcott Avenue, Room E714, Chicago, IL 60612, USA

Full list of author information is available at the end of the article permits use, sharing, adaptation, distribution and reproduction in any medium or format, as long as you give appropriate credit to the original author(s) and the source, provide a link to the Creative Commons licence, and indicate if changes were made. The images or other third party material in this article are included in the article's Creative Commons licence, unless indicated otherwise in a credit line to the material. If material is not included in the article's Creative Commons licence and your intended use is not permitted by statutory regulation or exceeds the permitted use, you will need to obtain permission directly from the copyright holder. To view a copy of this licence, visit http://creativecommons.org/licenses/by/4.0/. The Creative Commons Public Domain Dedication waiver (http://creativecommons.org/publicdomain/zero/1.0/) applies to the data made available in this article, unless otherwise stated in a credit line to the data. 


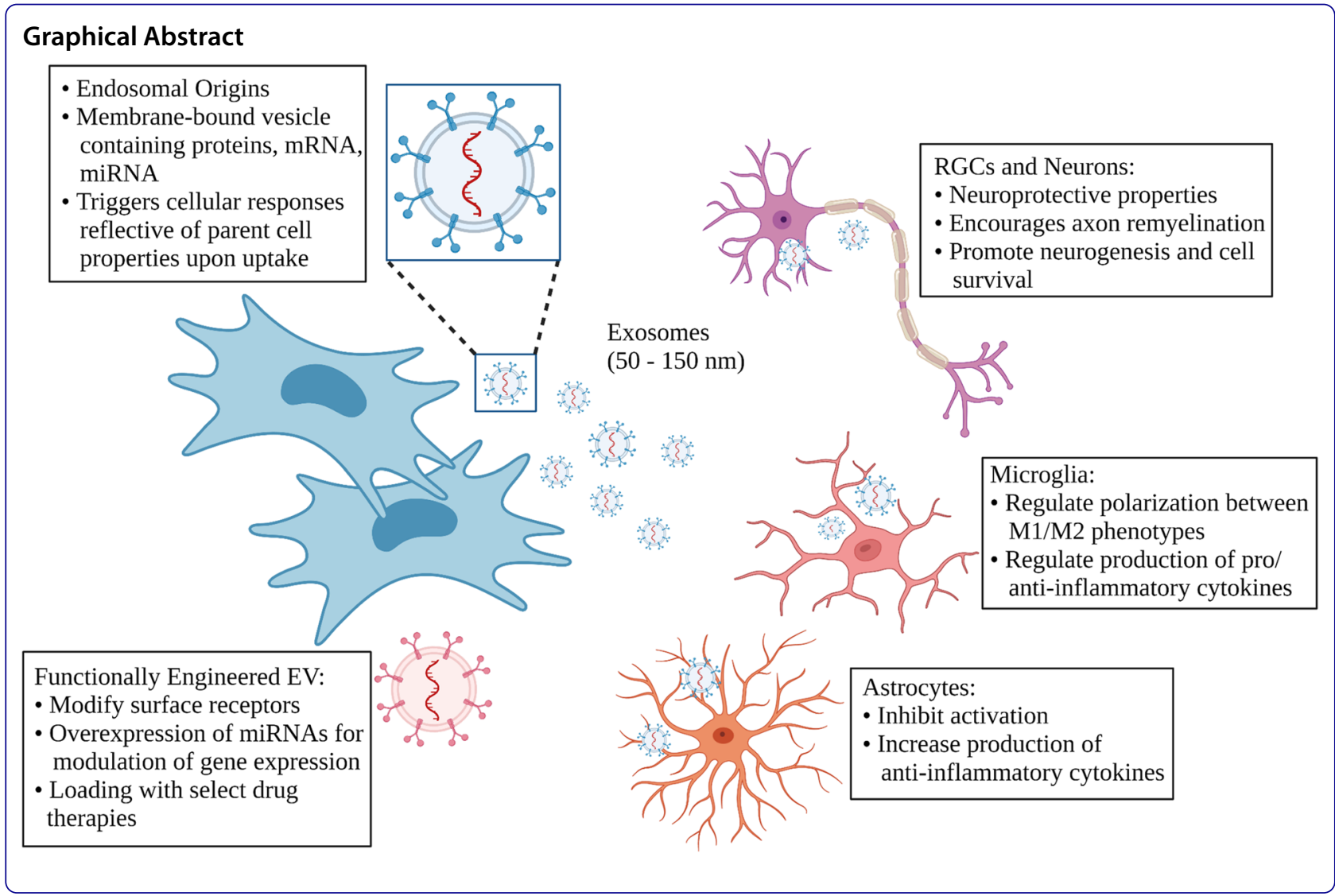

\section{Background}

\section{Clinical scope of optic neuritis}

Optic neuritis $(\mathrm{ON})$ is an inflammatory condition of the optic nerve often associated with central nervous system demyelinating disorders including multiple sclerosis (MS), neuromyelitis optica spectrum disorder (NMOSD), anti-myelin oligodendrocyte glycoprotein associated disease (MOGAD), as well as other systemic autoimmune disorders [1]. ON is characterized by inflammation and demyelination of the optic nerve and inner retinal damage [2].

The presence of antibodies targeting the water channel aquaporin 4 in patients with NMOSD and myelin oligodendrocyte glycoprotein in MOGAD are distinguishing features from MS [3]. The incidence of ON has been estimated in large population studies. In a nationwide database of 44 million people in South Korea, the incidence was 1.04 per 100,000 children, and 3.29 per 100,000 from 2010 to 2016 [4]. In the adult population, it was 5.36 per 100,000 in a hospital discharge database in Spain from 2008 to 2012 [5], and 3.7 per 100,000 in the United Kingdom Health Improvement Network from January 1, 1995, to September 1, 2019. Patients with ON had a significantly higher rate of incident MS (hazard ratio, 284.97; 95\% confidence intervals, 167.85-483.81) [6].

Optic neuritis is a clinical diagnosis based on vision loss, optic nerve dysfunction, and absence of symptoms suggesting alternative forms of optic neuropathy. Magnetic resonance imaging typically shows enhancement of the impacted optic nerve segment, and visual evoked potentials demonstrate prolonged latency [7]. In up to $25 \%$ of MS patients, ON is the initial inflammatory event [8-10]. Approximately 50\% experience ON during the course of their disease [9].

Symptoms of eye pain and blurred vision may worsen over the first few days to 2 weeks, and then gradually improve. Some recover within a month, but recovery could take up to a year. In a 6-month followup of 278 patients in Optic Neuritis Treatment Trial [11] with baseline visual acuity of $>20 / 50$, all improved at least one line of visual acuity, and all except six improved at least three lines [12]. However, the quality of vision, including color or depth perception and contrast sensitivity, may be reduced due to optic nerve demyelination $[13,14]$. Vision loss from $\mathrm{ON}$ in neuromyelitis optica spectrum disorder is usually more severe than MS-associated ON, with larger scotomas, and bilateral vision loss is common. The 
risk of long term loss of vision is significantly greater than in MS, with approximately $20-30 \%$ functionally blind in the affected eye $[15,16]$. Anti-myelin oligodendrocyte glycoprotein associated disease is also associated with significant bilateral visual impairment, but marked ONrelated papillitis and long term loss of vision occurs less frequently than in NMOSD [17].

\section{Pathophysiology of ON}

Hallmarks of ON pathology in the acute phase are optic nerve abnormalities and inflammatory demyelination. Predominant T-, B-, and glial cell activation within the nerve increases pro-inflammatory cytokines [18]. Inflammation caused by activated microglia, monocyte-derived macrophages, and CD4- and CD8 $+\mathrm{T}$ cells results in reactive gliosis, demyelination, and axonal death [19]. Pro-inflammatory cytokines and cytotoxic factors target myelin-producing oligodendrocytes (OLGs), and oligodendrocyte precursor cells (OPCs), causing apoptosis [20-22], exacerbating axonal demyelination [23-28]. Mature OLGs that survive demyelination are unable to produce new myelin sheaths. Remyelination therefore requires migration and regeneration of oligodendrocytes from OPCs $[29,30]$. These acute inflammatory lesions of the afferent visual pathway cause retrograde degeneration of retinal ganglion cells (RGCs) [31, 32]. Retinal nerve fiber layer (RNFL), and inner retinal layer thinning $[33,34]$ are quantified by optical coherence tomography (OCT). The extent of retinal thinning predicts the disease outcomes [35].

Jin et al. studied the time course of glial activation and its correlation to axon loss in the optic nerve and found that RGC loss was associated with reduced post-synaptic proteins and neurite projections, persistent microglia, and astroglia activation in the inner retina with high levels of iNOS (inducible nitric oxide synthase), IL (interleukin)-1 $\alpha$, TNF (tumor necrosis factor)- $\alpha$, and C1q (complement component 1q) [23]. Hence, development of therapeutic agents should focus on anti-inflammatory, anti-apoptotic, and remyelinating properties to achieve neuroprotection and neuro-regeneration in the optic nerve and retina.

\section{Main text}

\section{Available and current treatment}

\section{Steroids}

High dose intravenous steroids are frequently used for treatment of MS-associated $\mathrm{ON}$, based upon results of the now 30-year old Optic Neuritis Treatment Trial [11].
However, there did not appear to be a long-term benefit from a single course of intravenous steroid treatment, and those treated with oral steroids had worse outcomes $v s$ intravenous steroids or no treatment at all.

2. Chemotherapy and autologous hematopoietic stem cell transplant

A major focus of research in MS and related neurological disorders is immunosuppression using chemotherapy and immune-depleting antibodies, followed by autologous hematopoietic stem cell transplant (aHSCT) [36]. The rationale is that MS is driven by inflammatory $\mathrm{T}$ cells that enter and infiltrate the central nervous system (CNS) and then recirculate in the cerebrospinal fluid (CSF) [37]. Harris et al. investigated $\mathrm{T}$ cell clones in the intrathecal compartment in active relapsing remitting MS and found that aHSCT removed most of them, establishing a new immune repertoire in both intrathecal and peripheral blood compartments. However, there have been significant complications that limit this therapy [38].

\section{Immune reconstitution therapy}

Up to $80 \%$ of NMOSD patients have circulating autoantibodies targeting aquaporin-4 (AQP4-IgG) on astrocytes [39]. Monoclonal antibodies that target complement (eculizumab), CD19 (inebilizumab), and interleukin-6 receptor (satralizumab) have been shown effective to prevent attacks in NMOSD in Phase III trials [40], and are a major focus of research and ongoing clinical studies.

The rationale behind anti-complement therapy is the activation of complement in subjects with NMOSD and MOGAD [41, 42]. For eculizumab, the largest study was of 143 patients, showing a significant decrease in rate of relapse [43]. IL6 is a proinflammatory cytokine increased in NMSOD, and the target of satralizumab. In Phase II studies, satralizumab decreased the rate of relapse [44]. Inebilizumab depletes circulating B cells, and is undergoing Phase II/III trials [45]. The outcomes of major trials of these agents have been extensively reviewed elsewhere [40].

\section{Limitations and gaps in existing therapies}

Steroids are limited by systemic effects, and oral steroids increased the risk of recurrence of ON [11]. In hematopoietic stem cell transplant, a primary concern is secondary autoimmune disease (2ndAD), typically autoimmune cytopenia, idiopathic thrombocytopenic purpura, autoimmune hemolytic anemia, hypo- or hyperthyroidism [46], and myasthenia gravis. 2ndADs were attributed to allogenic imbalances contextualized 
by graft versus host disease, viral infections, and chronic immunosuppression [46]. Alping et al. compared the monoclonal antibody alemtuzumab, aHSCT, and a reference group of non-induction therapies between 2008 and 2017 [47]. The mortality rate of aHSCT was comparable to the reference group and was lower than that in previous reports, but there was increased infection and thyroid disease $v s$ the reference group. A potential limitation of the study includes the lack of a longitudinal component as outcomes were only measured up to 3 years after treatment [48].

Monoclonal antibodies have been approved by the FDA and are safe. The main risk of eculizumab is infection by Neisseria meningitidis, with vaccination now required to prevent meningitis. There are practical considerations with all of the agents, including the need for tightly scheduled and frequent infusions, as well as cost. The estimated yearly cost of eculizumab in the USA is $\$ 710,000$. The cost of the other agents is about $1 / 2$ or less that of eculizumab [49].

Due to the recurrent nature of the illness, the lack of long term benefit of steroids, changing nature of the disease with increasing recognition of NMSOD and MOGAD, and occurrence of residual damage to the optic nerve, therapeutic alternatives are needed for ON [18]. In particular, there is a need for agents that can assist with regeneration, and restoring neurological and visual function. Accordingly, in this review we will focus on mesenchymal stem cells and their secreted EVs (exosomes), which have the advantages of autologous treatment, fewer side effects, potential for regeneration of lost neurons, and preservation of vision, and projected lower cost than existing therapies.

\section{Mesenchymal stem cells}

\section{General considerations in MS and related disorders:}

To promote neuroprotection in $\mathrm{ON}$, attenuation of the inflammatory response, and neuroprotection of glial cells (OLGs, OPCs, astrocytes) and RGCs are key. MSC therapy is a promising approach to reducing the severity of MS-ON by triggering remyelination [50]. MSCs also suppress activation of T-, B-, dendritic, and NK (natural killer) cells [51-54]. It is important to note, however, that most of these studies have been performed in mouse EAE and are not necessarily extrapolatable to other models. Their immunomodulatory properties have been demonstrated in animal models of MS, with intravenous administration of MSCs in EAE mice inhibiting T-cell responses and improving clinical scores [55]. Subsequent studies further demonstrated that MSCs decrease production of inflammatory cytokines, reduce axonal loss, attenuate demyelination, and improve functional recovery in $\mathrm{EAE}$ mice and rats when administered prior to disease onset [56-58]. However, all studies in EAE found that while MSCs were able to migrate into the central nervous system via intravenous injection, they did not differentiate into neural phenotypes. Methods for delivering MSCs for MS-ON currently include intravitreal and systemic injection and intranasal delivery.

\section{MSCs and optic neuritis:}

(i) Intravitreal administration: An intravitreal injection of MSCs is feasible as a means to reach the dysfunctional retinal ganglion cells. Injection of MSCs into the vitreous in a rodent model rescued the retina from ischemic damage by suppression of apoptosis, preserved autophagy, and attenuation of inflammation and vascular permeability [59-61]. Intravitreally transplanted MSCs may also function by donating functional mitochondria to retinal ganglion cells [62]. Similarly, neural stem cell-based factors, glial derived neurotrophic factor (GNTF) or ciliary neurotrophic factor (CNTF), synergistically protected injured RGCs from cell death in an optic nerve crush model [63]. The main drawback of this approach is that the MSCs did not enter the optic nerve [64].

(ii) Parenteral administration: A recent animal study in mice with EAE showed promising results with MSCs for treatment of ON. Mice received $10^{6}$ cells intraperitoneally. There was significantly lower motor-sensory impairment, improved pattern electroretinogram, and preserved retinal nerve fiber layer. Increased expression of Abca1, a cholesterol efflux regulatory protein, and reduced HIF-1 were present, although the functional roles of these gene expression alterations were not examined, leaving the mechanism of improvement still uncertain [65].

In a Phase IIa open label study, intravenous administration of autologous MSCs (mean dose of $1.6 \times 10^{6}$ cells $/ \mathrm{kg}$ ) improved visual function in MS patients with optic neuritis. Visual acuity, visual evoked response latency and optic nerve area improved, and retinal nerve fiber layer was preserved. This study lacked a control group and could not differentiate between treatment and the natural course of the disease [66]. In an observational study of 15 patients with NMOSD, $10^{8}$ autologous MSCs were given intravenously, and $\mathrm{T} 2$ or gadolinium-enhancing $\mathrm{T} 1$ lesions decreased in the optic nerve. Visual acuity, retinal nerve fiber layer thickness, and optic nerve diameter increased [67].

(iii) Intranasal administration: Intranasal administration of stem cells and other drugs bypasses the blood brain barrier, enabling non-invasive delivery to the optic nerve and brain [68]. While there are not yet any 
studies of intranasal MSCs in ON, there are promising results from pre-clinical studies in other neurodegenerative diseases. Bone-marrow MSCs preconditioned with fasudil suppressed immune response in a mouse model of Parkinson's disease, decreasing dopaminergic neuron loss and improving motor function. MSCs migrated to hippocampus and substantia nigra for up to 1 month after intranasal administration [69]. Improved migratory ability of MSCs following intranasal administration was also noted in a study of cerebral ischemia in mice. The co-delivery of MSCs and insulin growth factor (IGF-1) resulted increased neurogenesis and angiogenesis in the ischemic region, leading to improved functional recovery [70]. Other examples of intranasal MSC administration include in models of neonatal stroke, encephalopathy of prematurity, Alzheimer's disease and EAE [71-74].

Validating this approach for $\mathrm{ON}$ is that intranasal administration of MSC secretome to mice with EAEinduced $\mathrm{ON}$ attenuated inflammation, demyelination, and RGC loss [75-77]. ST266, given intranasally to EAE mice resulted in decreased vision loss, inflammation, and demyelination. ST266 is derived from amnion-derived multipotent progenitor cells, a subpopulation of amnion epithelial cells grown in serum free media. The concentration of proteins in ST266 ranges from the $\mathrm{pg} / \mathrm{mL}$ to $\mathrm{ng} / \mathrm{mL}$ range, and total concentration of secretome proteins is about $100 \mu \mathrm{g} / \mathrm{mL}$ [78]. Filtered ST266 with elements $<50 \mathrm{kD}$ did not have significant effects in the retina; the effects could be due, at least in part, to the presence of EVs in the mixture (see below). There was localized accumulation of ST266 in the retina and optic nerve, and significant neuroprotection of RGCs [79]. Intranasal ST266 in mice with optic nerve crush rescued RGCs, decreased demyelination, and provided neuroprotection for up to 10 days [80]. The exact routes of transport of drugs after intranasal administration still remain under investigation [81]. ST266 is currently in Phase I trials via intranasal administration in patients with intraocular hypertension who have not yet developed optic nerve damage [49].

Use of MSCs is limited by their cellular senescence [82], possibility of malignant transformation in long-term culture [83], and low survival rate in tissues [84]. Most mesenchymal stem effects are paracrine, likely mediated by extracellular vesicles (EVs) [85-87]. Administration of MSCs or their secretome, which demonstrate neuroprotective properties [88], suggests EVs can serve an alternative cell-free strategy for restoring axons and their myelination [72].

Mesenchymal stem cell-derived extracellular vesicles (EVs) EVs secreted by living cells mainly include exosomes (50-150 nm diameter) and microvesicles (100-1000 nm)
[89]. MSCs are amongst the largest cellular producers of EVs [90]. Although originally believed to be mediators of cellular homeostasis by secreting cellular waste [91], recent studies have highlighted important roles of EVs in intracellular communication and as modulators of cellular immunity, cancer biology, and regeneration [91, 92]. The EV membrane's lipid bilayer is a subset of the plasma membrane [93]. EVs contain messenger RNA (mRNA), microRNA (miRNA), cytosolic, and trans-membrane proteins [94]. Exosomes are the smallest subset of EVs and play a significant role in the transfer of biomolecules such as RNA, proteins, enzymes, and lipids in physiological and pathological conditions $[95,96]$.

A defining characteristic of exosomes is their endosomal origin [97]. Exosome production starts with reverse membrane invagination and processing in multivesicular bodies (MVBs), followed by release into the intercellular fluid when MVBs fuse with the cell membrane. All exosomes share a common set of proteins, tetraspanins (CD9, CD63, CD81), Alix, and TSG101, but also contain cargo reflective of the parent cell $[96,98]$. When endocytosed by effector cells, EVs trigger cellular responses reflective of their cell of origin $[99,100]$.

As a cell-free therapy, EVs have potentially significantly greater safety and specificity compared to stem cells [101], can be safely administered cross-species without immunosuppression [102-104], and are efficient small molecule carriers that can deliver anti-inflammatory agents [105-107]. EVs can pass through the blood brain barrier [105], making them suitable for CNS treatment. MSC-EV stability, biocompatibility, and low toxicity make them a favorable direction for research in drug delivery and precision medicine. However, challenges exist in large-scale exosome production, isolation, and storage stability [108]. Below we will cover recent findings on the neuroprotective role of MSC-derived EVs and discuss the plausibility of MSC-EVs as a translationally relevant cell-free therapy for MS- and related disease induced $\mathrm{ON}$.

\section{Therapeutic effects of EVs in neurodegenerative diseases} Neuronal EVs, including those secreted by oligodendrocytes, are involved in signaling between neural circuits to promote development and function by increasing neurogenesis, synaptogenesis, and network activity [109]. Microglia-derived EVs promote production of ceramide and sphingosine to enhance excitatory neurotransmission, which supports physiological modulation of synaptic activity by microglia [110, 111]. Astroglial (astrocyte) EVs play key roles in regulating extracellular glutamate levels and modulating synaptic activation. MSC-derived EVs are involved in a wide variety of physiological processes including inhibiting natural killer cells, B cells, 
Table 1 MSC-EVs as potential therapy for MS, and related neurodegenerative diseases

\begin{tabular}{|c|c|c|c|c|c|}
\hline Disease & Model & Administration & Molecular mechanism & Effect & References \\
\hline \multirow[t]{4}{*}{ MS } & EAE Rat & Intravenous & $\begin{array}{l}\text { Regulated polarization of microglia } \\
\text { M1-M2 }\end{array}$ & $\begin{array}{l}\text { Attenuated demyelination and } \\
\text { decreased inflammation }\end{array}$ & [141] \\
\hline & EAE Mice & Intravenous & $\begin{array}{l}\text { Reduced T-cell proliferation and } \\
\text { increased regulatory T-cell activity } \\
\text { through anti-inflammatory cytokines }\end{array}$ & $\begin{array}{l}\text { Improved functional outcomes and } \\
\text { clinical score, reduced demyelination }\end{array}$ & [138] \\
\hline & EAE Mice & Intravenous & $\begin{array}{l}\text { Induced anti-inflammatory TH-2 } \\
\text { cytokines and TGF- } \beta\end{array}$ & $\begin{array}{l}\text { Modulated immune response and } \\
\text { induced peripheral tolerance }\end{array}$ & [132] \\
\hline & TMEV-IDD Mice & Intravenous & Decreased Th-1/Th-17 cytokines & Improved motor deficits & [131] \\
\hline \multirow[t]{2}{*}{ Alzheimer } & APP/PS1 Mice & Intravenous & $\begin{array}{l}\text { Inhibited astrocyte activation, } \\
\text { decreased pro-inflammatory and } \\
\text { increased anti-inflammatory cytokines }\end{array}$ & $\begin{array}{l}\text { Alleviated plaque deposition and } A \beta \\
\text { accumulation, improving cognitive } \\
\text { function }\end{array}$ & [148] \\
\hline & 3xTg Mice & Intranasal & $\begin{array}{l}\text { Regulated polarization of microglia } \\
\text { M1-M2 }\end{array}$ & $\begin{array}{l}\text { Neuroprotective effects, increased } \\
\text { dendritic spine density }\end{array}$ & [143] \\
\hline Status Epilepticus & Pilocarpine Mice & Intranasal & $\begin{array}{l}\text { Decreased glutamatergic and GABAe- } \\
\text { rgic neurons, regulation of pro/anti- } \\
\text { inflammatory cytokines }\end{array}$ & $\begin{array}{l}\text { Neuroprotective effects, preserved } \\
\text { cognitive and memory function }\end{array}$ & [128] \\
\hline Stroke & MCAO Rats & Intravenous & $\begin{array}{l}\text { miR-133b regulated CTGF in astrocytes, } \\
\text { increasing axonal plasticity }\end{array}$ & Induced functional recovery & [149] \\
\hline \multirow[t]{2}{*}{ Glaucoma } & ONC Mice & Intravitreal & $\begin{array}{l}\text { Improved retinal ganglion cell survival, } \\
\text { downregulated cis-p tau }\end{array}$ & Improved cognitive visual behavior & {$[150]$} \\
\hline & ONC Rats & Intravitreal & $\begin{array}{l}\text { Modulated inflammatory response } \\
\text { through miR-based mechanisms }\end{array}$ & $\begin{array}{l}\text { Neuroprotection of retinal ganglion } \\
\text { cells }\end{array}$ & [130] \\
\hline
\end{tabular}

CTGF, Connective tissue growth factor; EAE, Experimental animal encephalomyelitis; MCAO, Middle cerebral artery occlusion; MS, Multiple sclerosis; ONC, Optic nerve crush; TMEV-IDD, Theiler's murine encephalomyelitis virus induced demyelinating disease

and mitogen activated $\mathrm{T}$ cells $[112,113]$, moderating microglia and macrophage polarization [114, 115], and reducing oxidative stress [116]. They also function in tissue regeneration and myelin membrane biogenesis [117-121]. While EVs derived from various types of neuronal cells have been studied as possible therapy for CNS diseases, they are applied as drug carriers or must be genetically modified to induce desired effects in target cells $[106,122]$. In contrast, MSC-EVs' inherent roles in immune modulation, neuroprotection, and anti-inflammatory mechanisms make them an ideal choice for the treatment of $\mathrm{ON}$ and other neurodegenerative disorders. The relative efficacy of these EVs derived from different cell types remains a significant knowledge gap in the field.

Intranasally administered EVs have shown promising results in rodent models of Alzheimer Disease, and other models of neurodegeneration [123-126]. Other studies found intranasal administration of EVs reduced neuroinflammation and neurodegeneration in models of MS [106], Parkinson's Disease [127], and prevented cognitive dysfunction in a model of status epilepticus [128]. Bone marrow human MSC-derived exosomes were given intranasally to 5XFAD transgenic mice in a model of Alzheimer Disease, and saw decreased amounts of $A \beta$ plaques and increased memory. To localize the exosomes in the brain, the investigators stained used a fluorescent label of the exosome membrane. Immunohistochemistry showed high fluorescence in the pre-frontal cortex of treated mice $24 \mathrm{~h}$ post-treatment, demonstrating the ability of exosomes to reach the CNS via intranasal administration [123]. EVs have been administered into the vitreous to access the retina, but no studies have been performed yet with intranasal administration directly targeting the optic nerve [104, 129, 130]. Novel methods of modifying surface receptors and contents of EVs to better target and protect the retina and optic nerve are currently being developed, which will be discussed below, and present a promising outlook for the application of EVs for the treatment of $\mathrm{ON}$.

\section{Mechanisms of MSC-EV activity relevant to ON}

\section{Anti-inflammation}

Increasing evidence suggests that EVs attenuate neuroinflammation through regulating T-cells, macrophages, astrocytes, and microglia [131-137]. Studies on MSCEVs in MS and neurodegenerative disease models are summarized in Table 1. MSC-EVs improved functional outcome and decreased levels of neuroinflammation and demyelination by reducing pro-inflammatory cytokines as well as $\mathrm{CD} 4+\mathrm{T}$ cells infiltrating the spinal cord in EAE mice $[132,138]$. EVs suppressed T-cell proliferation 
Table 2 MicroRNAs in MS and demyelination animal models

\begin{tabular}{|c|c|c|c|}
\hline miRNA & Disease Model & Effect in Diseased Model & References \\
\hline miR-21 & Pediatric Multiple Sclerosis & Increased levels in white matter & [154] \\
\hline miR-219 & Demyelinating model & $\begin{array}{l}\text { CNS myelination and remyelination after injury, overexpression promotes early } \\
\text { oligodendrocyte maturation }\end{array}$ & [155] \\
\hline miR-219 & Multiple Sclerosis & Necessary for production of myelinating oligodendrocytes & [156] \\
\hline miR-146 & Multiple Sclerosis (EAE Model) & Crossed the Blood Brain Barrier and significantly improved functional recovery & [157] \\
\hline miR-197 & Pediatric Multiple Sclerosis & Essential for maintaining T-cell count in patients treated with IFN-beta & [154] \\
\hline miR-200c & Pediatric Multiple Sclerosis & Increased levels in white matter & [154] \\
\hline miR-326a & Multiple Sclerosis & Increased levels in T-cell derived EVs in MS patients & [158] \\
\hline
\end{tabular}

and induction of regulatory $\mathrm{T}$ cells (Tregs), whose deletion or mutation play an important role in the pathogenesis of EAE $[138,139]$.

As the resident immune cells of the CNS, microglia play an important role in initiating and attenuating neuroinflammation. Mounting evidence suggests the role of MSC-EVs in mediating immunomodulatory effects by regulating microglial activity and promoting a shift in microglial phenotypes from M1 (pro-inflammatory) to M2 (anti-inflammatory) [131, 136, 140]. For example, MSC-EVs administered intravenously to EAE mice improved symptoms, attenuated demyelination, and decreased neuroinflammation by regulating polarization of microglia between M1 and M2 phenotypes [141]. In a murine model of Alzheimer's disease, MSC-EVs inhibited the activation of microglia through transfer of microRNAs-467f and -466q, decreasing expression of proinflammatory cytokines [142]. Intranasal administration of MSC-EVs to a 3xTg mice model of Alzheimer's disease reduced pro-inflammatory cytokine secretion from microglia, while enhancing the secretion of anti-inflammatory cytokine IL-10 [143].

\section{Axon remyelination and MSC-EVs}

In MS and related disorders, activated immune cells in inflammatory lesions damage myelin-producing oligodendrocytes, causing demyelination. Several studies have shown MSC-EVs' ability to protect and promote the development of OLGs and their precursor cells throughout the course of the disease. EAE mice injected with MSC-EVs had improved motor function and decreased demyelination in the spinal cord. EVs also promoted differentiation of OLG precursor cells into mature OLGs [144]. But this study has significant limitations. There was large variability in onset of EAE, with significant sex differences in the onset and response to treatment. The neuroprotective effects of MSC-EVs on oligodendrocytes were also reported in models of ischemic brain injury. MSC-EVs boosted remyelination and increased mature oligodendrocyte and neuronal cell counts, leading to significantly improved learning ability in mice with perinatal brain injuries [10]. Mice exposed to hypoxia were injected with EVs which attenuated demyelination, increased proliferation of endothelial cells, and increased the number of mature OLGs [145]. The neuroprotective effects of the EVs were largely attributed to their ability to modulate activation of microglia and astrocytes. In TMEV-IDD (TMEV-induced demyelinating disease) mice, MSC-EVs reduced brain atrophy, and cytokine levels [131].

It is important to note that most of these studies are limited by inability to track the effects of EVs over an extended period, and more importantly, that EVs typically do not last long in tissues [10, 103, 131, 141-143]. Thus, the temporal sequence of improvement is difficult to assess. Fluorescent tracking of EVs after intravenous injection found that the administered EVs collected largely in the spleen and liver in as little as two hours, and no significant amounts remained in the CNS after a week [131, 138].

Analysis of cytokine levels from the in vivo studies is also limited, as mRNA expression was analyzed in total tissue lysates, not allowing conclusions about their cellular source $[138,143,145,146]$. More research on uptake and distribution of EVs in disease models will allow better understanding of their full potential, limitations and explain discrepancies between in vivo and in vitro results $[139,142]$.

There also is a need to develop EVs formulations that possess extended periods of uptake into tissues. Initial studies by our group in bone regeneration using EVs tethered to hydrogels have shown the ability to produce an extended-release formulation [147]. More discussion of the means to prolong delivery of EVs appears below.

\section{MicroRNA mediated EV functionality}


The pathology of MS is influenced by histone modifications and gene regulation by microRNAs (miRNA) [151]. Thus, microRNAs are emerging as important mediators in MS and related disorders (Table 2) [152, 153]. Although exosomes carry proteins, mRNAs, and other non-coding RNAs, microRNAs are among the most important components of exosomes that mediate changes in cellular signaling. Exosomes can play a role as carriers of miRNAs to therapeutically regulate MS pathology. Additionally, overexpression of proteins that modulate exosomal miRNA gene expression profiles have the potential to improve therapeutic effects of exosomes [108].

MicroRNAs mediate post-transcriptional gene silencing and are involved in cellular activities including proliferation, differentiation, and migration, as well as disease initiation and disease progression. MicroRNA appears to mediate most EV effects [159] by three known mechanisms: [1] Binding the 3'UTR of their target mRNA, silencing the gene and blocking translation, [2] Translational repression by cleaving and degrading mRNA, [3] De-adenylation and degradation of mRNAs [160]. The miRNA processing endonuclease Dicer is a member of the ribonuclease III family that functions in the RNA interference pathway to cleave long double stranded RNA molecules into small RNAs including miRNA and siRNA $[161,162]$. Dicer1 is essential to the miRNA pathway and Dicer2 facilitates the siRNA pathway [161]. Dicer cleaves the precursor miRNA (pre-miRNA) hairpins at the stemloop boundary, generating mature miRNA [162]. ADicer knockout mice (ADicerKO) lack effective miRNA processing in adipose tissue. EVs from ADicerKO mice exhibited significant alterations in $422 \mathrm{EV}$ miRNAs [163].

MicroRNA-219 promoted oligodendrocyte maturation and regeneration in the EAE model [155]. Its gene targets were oligodendrocyte inhibitors including Nfia, Nfib, and Lingo1 in OPCs. Similar findings have been found in an animal model of Krabbe's disease [164]. MicroRNA125a-3p was upregulated in MS patients and in OPCs from the spinal cord of EAE mice; blocking this microRNA accelerated remyelination [165]. Similarly, increased levels of miR-27a were found in OPCs from MS patients and in animal models of demyelination [166]. Studies on microRNAs in MS and related disorders are summarized in Table 2. MicroRNA regulation of OPCs is an emerging field with significant implications for design of treatment strategies in MS. In addition to viral transfection [165], another means to deliver microRNAs is via EVs.

\section{Modification of EVs for targeted delivery and functionality}

Regardless of the route of administration, EVs are highly promiscuous and tend to enter the first cells they encounter. This can limit the ability of EVs to reach cells that are further from the site of administration. The surface of EVs can be modified to carry ligands to take advantage of the presence of specific receptors on the cell surface for targeting and thereby deliver the EVs to the desired cell types. The first use of this methodology was engineering EVs from dendritic cells to express neuron-specific rabies viral glycoprotein peptide, to bind the acetylcholine receptor on neurons [167]. EVs conjugated to a monoclonal antibody against GAP43 targeted delivery of quercetin to ischemic neurons [168]. Another example was T7, a transferrin receptor-binding peptide attached to the EV surface, which resulted in targeting of gliomas [169]. With respect to MS specifically, carboxylic acid-functionalized LJM-3064 aptamer was covalently conjugated to amine groups on the EV surface, which resulted in proliferation of OLGs in vitro. In mice, these EVs suppressed inflammatory response and decreased demyelination [170]. Targeting of EVs, while an exciting technology, still faces significant technical hurdles. Chemical modifications of surface proteins and addition of monoclonal antibodies can alter endocytosis of EVs [171, 172].

An alternate approach is genetic modification, where the EV surface is modified using a lentiviral carried plasmid for transfection of the parent cells, as we and others previously reported [173-175]. With the genetic modification, a stable cell line of, e.g., MSCs, can be created, from which EVs of predictable composition and properties can easily be obtained [147].

Functionally engineered EVs (FEEs), where EVs are modified to carry proteins or specific miRNAs, are also emerging as a potential nano-therapeutic tool in the brain. In several different models, EVs overexpressing the miR17-92 cluster enhanced function and myelination [176, 177]. There are few studies available on the efficacy of functionally engineered MSC-EVs in EAE. Experiments have involved EAE mice with engineered EVs derived from phagocytes. In Zhuang et al's study, macrophage-derived EVs were complexed with the anti-inflammatory drug curcumin, and administered intranasally to EAE mice [106]. The EV-curcumin complex significantly reduced neural inflammation and disease severity score by lowering the number of activated inflammatory microglial cells $(\mathrm{CD} 45.2+\mathrm{IL}-1 \beta+)$. Engineered BV-2 microglia released EVs containing IL-4, an anti-inflammatory cytokine, which targeted phagocytes through the overexpression of Mfg- 8 on its surface [122]. A single injection of the EVs in EAE mice reduced neuroinflammation, improved clinical score, and attenuated tissue damage by up-regulating anti-inflammatory markers. Engineered extracellular vesicles from HEK $293 \mathrm{~T}$ cells overexpressing miR-219a-5p increased oligodendrocyte precursor cell differentiation and severity of EAE [178]. 
Table 3 EV-hydrogel delivery systems

\begin{tabular}{llll}
\hline Type of EV & Hydrogel Material & Application & References \\
\hline BMSC-EV & Thiol-modified hyaluronan, heparin, gelatin, and polyethylene glycol & Increased levels in white matter & [179] \\
HMSC-EVs & Photoinduced imine crosslinking hydrogel & Cartilage regeneration and repair & {$[180]$} \\
ADSC-EVs & Pluronic F127, oxidative hyaluronic acid, and Poly- - -L-lysine & Chronic diabetic wound healing & {$[181]$} \\
UMSC-EVs & Silk fibroin hydrogel & Aging-induced vascular dysfunction & {$[182]$} \\
PMSC-EVs & Chitosan hydrogel & Hindlimb Ischemia & {$[133]$} \\
GMSC-EVs & Chitosan and silk-based hydrogel & Diabetic wound healing & {$[183]$} \\
UMSC-EVs & PA-GHRPS and NapFF peptide hydrogel & Myocardial infarction & {$[182]$}
\end{tabular}

ADSC: Adipose tissue-derived mesenchymal stem cells; GMSC: Gingival mesenchymal stem cells; PMSC: Placental mesenchymal stem cells; UMSC: Umbilical cordderived mesenchymal stem cells

\section{Prolonging EV delivery}

With a short half-life in tissues, one of the biggest challenges in developing EVs for therapeutics is to enhance their residence in the tissues. Loading of EVs into hydrogels for sustained release has been attempted in several organ systems. Hydrogels increase the efficacy of EVs by concentrating them in a single area. Li et al. encapsulated miR-26a-enriched MSC EVs in a biodegradable hydrogel made of thiol-modified hyaluronan (HA), heparin (HP), gelatin, and polyethylene glycol (PEG) and implanted them into calvarial defects in mice [179]. The hydrogel complex provided a controlled release of the miRenhanced EVs, successfully integrated with the host bone marrow cells, and sustained an upregulation of miR26a expression, leading to greater vascularization, bone regeneration, and complete repair of the calvarial bone defect. Other research groups have delivered EVs in a number of different biomaterials to target various disease models (Table 3). With the conjugated systems, sustained release of EVs was maintained for 14-36 days [180, 181]. The longer period of time and improved integration of EVs lead to significantly higher levels of wound healing, tissue repair, and blood perfusion, as well as decreased inflammation and apoptosis.

Natural and synthetic hydrogels allow for precise control of the types of materials, its shape, and the timing and level of its degradability. Coupled with its ability to enhance the therapeutic effects of exosomes, hydrogelEV systems have strong potential for clinical application.

\section{MSC-EVs: comparison to MSCs and challenges for clinical translation}

Compared to the MSCs from which they are derived, EVs have shorter lifespan and thus need for multiple injections $[103,130]$. MSCs can be injected or placed at the site of action, and while they may not integrate into the tissue, they may remain intact for a longer period of time. For example, after injection of CD +34 MSCs into the vitreous, the cells were found to have migrated into the retinal vasculature after about 4 months [184]. However, immunosuppression is needed to maintain the survival of the stem cells [185].

MSCs also have a migratory capacity [186], while for EVs studies of migration within tissues still remain incomplete. We found that MSC-EVs injected into the vitreous did not penetrate any deeper than the outer plexiform layer. (This is not, however, a disadvantage for access to inner retina and retinal ganglion cells) [103]. MSCs and EVs have different considerations for long term storage. Storage at low temperature $\left(-80{ }^{\circ} \mathrm{C}\right)$ may affect the stability of EVs [187]. Lyophilization or use of cryoprotective agents may mitigate these problems. With MSCs, cryopreservation may also impair their function [188]. Recent reviews have discussed these issues and novel means to preserve MSC function [189].

A major challenge with EVs is the accuracy of the methods in measuring the quantity and purity of exosomes. The different methods for quantitation of amount of EVs and their purity, as well as preparation methods, have been reviewed thoroughly elsewhere [190]. For regulatory approval, assuring purified preparations is essential. EV production requires culturing the parent cell line, harvesting EVs from conditioned media, and separation/ purification of contaminants. Large scale consistent production necessitates use of a bioreactor, to facilitate cell cultivation and continuous medium collection [191]. Good manufacturing practice will be essential for large scale production of EVs [192].

\section{Conclusions}

Demyelinating optic neuritis is a classic presentation of multiple sclerosis and related conditions including neuromyelitis optica spectrum disorder and anti-myelin oligodendrocyte glycoprotein associated disease. ON pathology is marked by an abnormal optic nerve and inflammatory demyelination. Clinical research has revealed efficacy of immunosuppressive treatment 
and monoclonal antibodies targeting different inflammatory pathways. However, achieving neuroprotection of glial cells and RGCs and remyelination are needed. Mesenchymal stem cell therapy is a promising approach that results in anti-inflammatory effects and remyelination and has shown success in some small clinical studies. The main limitation of MSC therapy for $\mathrm{ON}$ is the difficulty of reaching the site of pathology in the optic nerve and retina. This necessitates investigation of a cell-free approach that utilizes the paracrine effects of EVs produced by MSCs, which have the ability to cross the blood-brain barrier. EVs have potential to be an effective cell-free therapy because of their increased specificity and ability to be safely administered without immunosuppression. EV cellular uptake can be enhanced through genetic engineering of their parental cells. MSC-EVs decreased inflammation and enhanced remyelination in animal models of MS. Further investigation has found the significant role played by microRNA in the mediation and progression of MS. Overexpressing specific miRs promoted remyelination. Delivery of engineered EVs can be prolonged through a robust hydrogel-EV system, which sustains delivery of EVs to the target site. Further exploration of the potential for EVs enhanced through miRNA modification, functional engineering, and engineered hydrogel-EV systems is necessary to develop effective clinical translation for MS and related diseases related ON.

\begin{abstract}
Abbreviations
aHSCT: Autologous hematopoietic stem cell transplant; 2ndAD: Secondary autoimmune diseases; BBB: Blood brain barrier; CNS: Central nervous system; CNTF: Ciliary neurotrophic factor; CSF: Cerebrospinal fluid; C1q: Complement component 1q; EAE: Experimental autoimmune encephalomyelitis; EVs: Extracellular vesicles; GNTF: Glial derived neurotrophic factor; HA: Haluronan; HP: Heparin; iNOS: Inducible nitric oxide synthase; IGF: Insulin growth factor; IL: Interleukin-1 $a_{i}$ ISEV: International Society for EVs; TNF: Tumor necrosis factor-a; MCAO: Middle cerebral artery occlusion; MSC: Mesenchymal stem cell; mRNA: Messenger RNA; miRNA: MicroRNA; MR: Magnetic resonance; MOGAD: Anti-myelin oligodendrocyte glycoprotein associated disease; MS: Multiple sclerosis; MVBs: Multivesicular bodies; NK: Natural killer cells; NMO: Neuromyelitis optica; NMOSD: Neuromyelitis optica spectrum disorder; OLGs: Oligodendrocytes; OCT: Optical coherence tomography; ONC: Optic nerve crush; OPCs: Oligodendrocyte precursor cells; PEG: Polyethylene glycol; RGC : Retinal ganglion cell; RNFL: Retinal nerve fiber layer; siRNA: Small interfering RNA; Tregs: Regulatory T cells; TMEV-IDD: TMEV-induced demyelinating disease; VEP: Visual evoked potential.
\end{abstract}

\section{Acknowledgements}

Not applicable.

\section{Authors' contributions}

AA: Conception of the review, drafting of the manuscript, review of the manuscript. AL: Conception of the review, drafting of the manuscript, review of the manuscript. BM: Conception of the review, drafting of the manuscript, review of the manuscript. HEL: Conception of the review, drafting of the manuscript, review of the manuscript. DF: Conception of the review, drafting of the manuscript, review of the manuscript. SR: Conception of the review, drafting of the manuscript, review of the manuscript. All authors have read and approved the manuscript.

\section{Funding}

National Institutes of Health (Bethesda, MD, USA) Grants EY028690 and EY028690-02S1 to Dr. Roth, DE027404 to Dr. Ravindran, EY001792 to the Department of Ophthalmology and Visual Sciences at the University of Illinois at Chicago, EY026877 to the Department of Ophthalmology at Stanford University, Pilot Grant funding (Dr. Roth) by the National Center for Advancing Translational Sciences, National Institutes of Health, through Grant UL1TR002003 to the University of Illinois at Chicago; National Multiple Sclerosis Society (New York, NY, USA) Grant PP-1905-33986 to Dr. Roth; Glaucoma Research Foundation Shaffer Grant Award (San Francisco, CA, USA) to Dr. Roth; a Catalyst Award from the Chicago Biomedical Consortium (Chicago, IL, USA) to Dr. Roth; the Michael Reese Foundation (Chicago, IL. USA) to Dr. Roth; National Glaucoma Grant G2018168 from the Bright Focus Foundation (Clarksburg, MD, USA) to Dr. Mathew; Grants BX004852-03 and BX002625-06 from the Department of Veterans Affairs (Washington, DC, USA) to Dr. Feinstein; an unrestricted grant from Research to Prevent Blindness to Stanford University Department of Ophthalmology.

Availability of data and materials

Not applicable.

\section{Declarations}

Ethics approval and consent to participate

Non applicable.

\section{Consent for publication}

Not applicable.

\section{Competing interests}

The authors declare that they have no competing interests.

\section{Author details}

'Department of Anesthesiology, College of Medicine, University of Illinois, 835 South Wolcott Avenue, Room E714, Chicago, IL 60612, USA. ${ }^{2}$ Departments of Ophthalmology and Neurology \& Neurological Sciences, Stanford University, Palo Alto, CA, USA. ${ }^{3}$ Department of Oral Biology, College of Dentistry, University of Illinois at Chicago, Chicago, IL, USA.

Received: 20 Auqust 2021 Accepted: 31 October 2021

Published online: 04 December 2021

References

1. De Lott LB, Bennett $J$, Costello F. The changing landscape of optic neuritis: a narrative review. J Neurol. 2021. https://doi.org/10.1007/ s00415-020-10352-1.

2. Shin T, Ahn M, Kim J, Jung K, Moon C, Kim MD. Visual dysfunction in multiple sclerosis and its animal model, experimental autoimmune encephalomyelitis: a review. Mol Neurobiol. 2021;58(7):3484-93.

3. Prüss H. Autoantibodies in neurological disease. Nat Rev Immunol. 2021. https://doi.org/10.1038/s41577-021-00543-w.

4. Lee JY, Han J, Yang M, Oh SY. Population-based incidence of pediatric and adult optic neuritis and the risk of multiple sclerosis. Ophthalmology. 2020;127(3):417-25.

5. Martínez-Lapiscina EH, Fraga-Pumar E, Pastor X, Gómez M, Conesa A, Lozano-Rubí $R$, et al. Is the incidence of optic neuritis rising? Evidence from an epidemiological study in Barcelona (Spain), 2008-2012. J Neurol. 2014;261(4):759-67.

6. Braithwaite T, Subramanian A, Petzold A, Galloway J, Adderley NJ, Mollan SP, et al. Trends in optic neuritis incidence and prevalence in the UK and association with systemic and neurologic disease. JAMA Neurol. 2020;77(12):1514-23.

7. McNicholas N, Hutchinson M, McGuigan C, Chataway J. 2017 McDonald diagnostic criteria: a review of the evidence. Mult Scler Relat Disord. 2018;24:48-54.

8. Sørensen TL, Frederiksen JL, Brønnum-Hansen H, Petersen HC. Optic neuritis as onset manifestation of multiple sclerosis: a nationwide, longterm survey. Neurology. 1999;53(3):473-8. 
9. Kale N. Optic neuritis as an early sign of multiple sclerosis. Eye Brain. 2016;8:195-202.

10. Thomi G, Joerger-Messerli M, Haesler V, Muri L, Surbek D, Schoeberlein A. Intranasally administered exosomes from umbilical cord stem cells have preventive neuroprotective effects and contribute to functional recovery after perinatal brain injury. Cells. 2019;8(8):855.

11. Beck RW, Cleary PA, Anderson MM Jr, Keltner JL, Shults WT, Kaufman DI, et al. A randomized, controlled trial of corticosteroids in the treatment of acute optic neuritis. The Optic Neuritis Study Group. N Engl J Med. 1992;326(9):581-8.

12. Beck RW, Cleary PA, Backlund JC. The course of visual recovery after optic neuritis: experience of the Optic Neuritis Treatment Trial. Ophthalmology. 2020;127(4s):S174-81.

13. Nolan RC, Akhand O, Rizzo JR, Galetta SL, Balcer LJ. Evolution of visual outcomes in clinical trials for multiple sclerosis disease-modifying therapies. J Neuro-Ophthalmol: Off J N Am Neuro-Ophthalmol Soc. 2018;38(2):202-9.

14. Trobe JD, Beck RW, Moke PS, Cleary PA. Contrast sensitivity and other vision tests in the optic neuritis treatment trial. Am J Ophthalmol. 1996;121(5):547-53.

15. Gospe SM 3rd, Chen JJ, Bhatti MT. Neuromyelitis optica spectrum disorder and myelin oligodendrocyte glycoprotein associated disorderoptic neuritis: a comprehensive review of diagnosis and treatment. Eye (Lond). 2021:35(3):753-68.

16. Merle H, Olindo S, Bonnan M, Donnio A, Richer R, Smadja D, et al. Natural history of the visual impairment of relapsing neuromyelitis optica. Ophthalmology. 2007:114(4):810-5.

17. Chen JJ, Flanagan EP, Jitprapaikulsan J, López-Chiriboga ASS, Fryer JP, Leavitt JA, et al. Myelin oligodendrocyte glycoprotein antibody-positive optic neuritis: clinical characteristics, radiologic clues, and outcome. Am J Ophthalmol. 2018;195:8-15.

18. Toosy AT, Mason DF, Miller DH. Optic neuritis. Lancet Neurol. 2014;13(1):83-99.

19. Babbe H, Roers A, Waisman A, Lassmann H, Goebels N, Hohlfeld R, et al. Clonal expansions of $\mathrm{CD} 8(+) T$ cells dominate the $T$ cell infiltrate in active multiple sclerosis lesions as shown by micromanipulation and single cell polymerase chain reaction. J Exp Med. 2000;192(3):393-404.

20. Melero-Jerez C, Fernández-Gómez B, Lebrón-Galán R, Ortega MC, Sánchez-de Lara I, Ojalvo AC, et al. Myeloid-derived suppressor cells support remyelination in a murine model of multiple sclerosis by promoting oligodendrocyte precursor cell survival, proliferation, and differentiation. Glia. 2021:69(4):905-24.

21. Carlström KE, Zhu K, Ewing E, Krabbendam IE, Harris RA, Falcão AM, et al. Gsta4 controls apoptosis of differentiating adult oligodendrocytes during homeostasis and remyelination via the mitochondria-associated Fas-Casp8-Bid-axis. Nat Commun. 2020;11(1):4071.

22. Chamberlain KA, Chapey KS, Nanescu SE, Huang JK. Creatine enhances mitochondrial-mediated oligodendrocyte survival after demyelinating injury. J Neurosci. 2017;37(6):1479-92.

23. Jin J, Smith MD, Kersbergen CJ, Kam T-I, Viswanathan M, Martin K, et al. Glial pathology and retinal neurotoxicity in the anterior visual pathway in experimental autoimmune encephalomyelitis. Acta Neuropathol Commun. 2019:7(1):125.

24. Cannella B, Raine CS. The adhesion molecule and cytokine profile of multiple sclerosis lesions. Ann Neurol. 1995;37(4):424-35.

25. Navikas V, Link H. Review: cytokines and the pathogenesis of multiple sclerosis. J Neurosci Res. 1996;45(4):322-33.

26. Ferguson B, Matyszak MK, Esiri MM, Perry VH. Axonal damage in acute multiple sclerosis lesions. Brain. 1997;120(Pt 3):393-9.

27. Lucchinetti C, BrückW, Parisi J, Scheithauer B, Rodriguez M, Lassmann H. A quantitative analysis of oligodendrocytes in multiple sclerosis lesions. A study of 113 cases. Brain. 1999;122(Pt 12):2279-95.

28. Kirby L, Jin J, Cardona JG, Smith MD, Martin KA, Wang J, et al. Oligodendrocyte precursor cells present antigen and are cytotoxic targets in inflammatory demyelination. Nat Commun. 2019;10(1):3887.

29. Keirstead HS, Blakemore WF. Identification of post-mitotic oligodendrocytes incapable of remyelination within the demyelinated adult spinal cord. J Neuropathol Exp Neurol. 1997;56(11):1191-201.

30. Kuhlmann T, Miron V, Cui Q, Wegner C, Antel J, Brück W. Differentiation block of oligodendroglial progenitor cells as a cause for remyelination failure in chronic multiple sclerosis. Brain. 2008:131(Pt 7):1749-58.
31. Quinn T, Dutt M, Shindler KS. Optic neuritis and retinal ganglion cell loss in a chronic murine model of multiple sclerosis. Front Neurol. 2011;2:50.

32. Niwa M, Aoki H, Hirata A, Tomita H, Green PG, Hara A. Retinal cell degeneration in animal models. Int J Mol Sci. 2016;17(1):110.

33. Kupersmith MJ, Mandel G, Anderson S, Meltzer DE, Kardon R. Baseline, one and three month changes in the peripapillary retinal nerve fiber layer in acute optic neuritis: relation to baseline vision and MRI. J Neurol Sci. 2011;308(1-2):117-23.

34. Kupersmith MJ, Garvin MK, Wang JK, Durbin M, Kardon R. Retinal ganglion cell layer thinning within one month of presentation for optic neuritis. Mult Scler. 2016;22(5):641-8.

35. Larabee CM, Desai S, Agasing A, Georgescu C, Wren JD, Axtell RC, et al. Loss of Nrf2 exacerbates the visual deficits and optic neuritis elicited by experimental autoimmune encephalomyelitis. Mol Vis. 2016;22:1503-13.

36. Atkins HL, Bowman M, Allan D, Anstee G, Arnold DL, Bar-Or A, et al. Immunoablation and autologous haemopoietic stem-cell transplantation for aggressive multiple sclerosis: a multicentre single-group phase 2 trial. The Lancet. 2016;388(10044):576-85.

37. Harris KM, Lim N, Lindau P, Robins H, Griffith LM, Nash RA, et al. Extensive intrathecal $\mathrm{T}$ cell renewal following hematopoietic transplantation for multiple sclerosis. JCI Insight. 2020;5(2):e127655.

38. Sharrack B, Saccardi R, Alexander T, Badoglio M, Burman J, Farge D, et al. Autologous haematopoietic stem cell transplantation and other celIular therapy in multiple sclerosis and immune-mediated neurological diseases: updated guidelines and recommendations from the EBMT Autoimmune Diseases Working Party (ADWP) and the Joint Accreditation Committee of EBMT and ISCT (JACIE). Bone Marrow Transplant. 2020;55(2):283-306.

39. Valencia-Sanchez C, Wingerchuk DM. Emerging targeted therapies for neuromyelitis optica spectrum disorders. BioDrugs: Clin Immunothera Biopharm Gene Therapy. 2021;35(1):7-17.

40. Levy M, Fujihara K, Palace J. New therapies for neuromyelitis optica spectrum disorder. Lancet Neurol. 2021;20(1):60-7.

41. Takai Y, Misu T, Suzuki H, Takahashi T, Okada H, Tanaka S, et al. Staging of astrocytopathy and complement activation in neuromyelitis optica spectrum disorders. Brain. 2021;144(8):2401-15.

42. Keller CW, Lopez JA, Wendel EM, Ramanathan S, Gross CC, Klotz L, et al. Complement activation is a prominent feature of MOGAD. Ann Neurol. 2021. https://doi.org/10.1002/ana.26226.

43. Pittock SJ, Berthele A, Fujihara K, Kim HJ, Levy M, Palace J, et al. Eculizumab in aquaporin-4-positive neuromyelitis optica spectrum disorder. N Engl J Med. 2019;381(7):614-25.

44. Paton DM. Satralizumab: an interleukin-6 (IL-6) receptor antagonist for the treatment of neuromyelitis optica spectrum disorders. Drugs Today (Barcelona, Spain: 1998). 2021;57(3):209-18.

45. Cree BAC, Bennett JL, Kim HJ, Weinshenker BG, Pittock SJ, Wingerchuk $\mathrm{DM}$, et al. Inebilizumab for the treatment of neuromyelitis optica spectrum disorder (N-MOmentum): a double-blind, randomised placebocontrolled phase 2/3 trial. The Lancet. 2019;394(10206):1352-63.

46. Burt RK, Muraro PA, Farge D, Oliveira MC, Snowden JA, Saccardi R, et al. New autoimmune diseases after autologous hematopoietic stem cell transplantation for multiple sclerosis. Bone Marrow Transplant. 2021;56:1509-17.

47. Alping P, Burman J, Lycke J, Frisell T, Piehl F. Safety of alemtuzumab and autologous hematopoietic stem cell transplantation compared to noninduction therapies for multiple sclerosis. Neurology. 2021;96(11):e1574-84.

48. Miller AE, Chitnis T, Cohen BA, Costello K, Sicotte NL, Stacom R, et al. Autologous hematopoietic stem cell transplant in multiple sclerosis: recommendations of the National Multiple Sclerosis Society. JAMA Neurol. 2021;78(2):241-6.

49. https://clinicaltrials.gov/ct2/show/NCT03901781?spons=Noveome.

50. Rivera FJ, Aigner L. Adult mesenchymal stem cell therapy for myelin repair in multiple sclerosis. Biol Res. 2012;45(3):257-68.

51. Bartholomew A, Sturgeon C, Siatskas M, Ferrer K, McIntosh K, Patil $S$, et al. Mesenchymal stem cells suppress lymphocyte proliferation in vitro and prolong skin graft survival in vivo. Exp Hematol. 2002;30(1):42-8. 
52. Corcione A, Benvenuto F, Ferretti E, Giunti D, Cappiello V, Cazzanti F, et al. Human mesenchymal stem cells modulate B-cell functions. Blood. 2006;107(1):367-72.

53. Di Nicola M, Carlo-Stella C, Magni M, Milanesi M, Longoni PD, Matteucci $P$, et al. Human bone marrow stromal cells suppress T-lymphocyte proliferation induced by cellular or nonspecific mitogenic stimuli. Blood. 2002;99(10):3838-43.

54. Spaggiari GM, Capobianco A, Becchetti S, Mingari MC, Moretta L. Mesenchymal stem cell-natural killer cell interactions: evidence that activated NK cells are capable of killing MSCs, whereas MSCs can inhibit IL-2-induced NK-cell proliferation. Blood. 2006;107(4):1484-90.

55. Zappia E, Casazza S, Pedemonte E, Benvenuto F, Bonanni I, Gerdoni E, et al. Mesenchymal stem cells ameliorate experimental autoimmune encephalomyelitis inducing T-cell anergy. Blood. 2005;106(5):1755-61.

56. Zhang J, Li Y, Chen J, Cui Y, Lu M, Elias SB, et al. Human bone marrow stromal cell treatment improves neurological functional recovery in EAE mice. Exp Neurol. 2005;195(1):16-26.

57. Zhang J, Li Y, Lu M, Cui Y, Chen J, Noffsinger L, et al. Bone marrow stromal cells reduce axonal loss in experimental autoimmune encephalomyelitis mice. J Neurosci Res. 2006;84(3):587-95.

58. Gerdoni E, Gallo B, Casazza S, Musio S, Bonanni I, Pedemonte E, et al. Mesenchymal stem cells effectively modulate pathogenic immune response in experimental autoimmune encephalomyelitis. Ann Neurol. 2007;61(3):219-27.

59. Kadzielawa K, Mathew B, Stelman CR, Lei AZ, Torres L, Roth S. Gene expression in retinal post-ischemic conditioning. Graef Archiv Clin Exp Ophthalmol. 2018;256:935-49.

60. Johnson TV, Bull ND, Hunt DP, Marina N, Tomarev SI, Martin KR. Neuroprotective effects of intravitreal mesenchymal stem cell transplantation in experimental glaucoma. Investig Ophthalmol Vis Sci. 2010:51(4):2051-9.

61. Yu S, Tanabe T, Dezawa M, Ishikawa H, Yoshimura N. Effects of bone marrow stromal cell injection in an experimental glaucoma model. Biochem Biophys Res Commun. 2006;344(4):1071-9.

62. Jiang $D$, Xiong $G$, Feng $H$, Zhang Z, Chen $P$, Yan B, et al. Donation of mitochondria by iPSC-derived mesenchymal stem cells protects retinal ganglion cells against mitochondrial complex I defect-induced degeneration. Theranostics. 2019;9(8):2395-410.

63. Dulz S, Bassal M, Flachsbarth K, Riecken K, Fehse B, Schlichting S, et al. Intravitreal co-administration of GDNF and CNTF confers synergistic and long-lasting protection against injury-induced cell death of retinal ganglion cells in mice. Cells. 2020;9(9):2082.

64. Chamling X, Sluch VM, Zack DJ. The potential of human stem cells for the study and treatment of glaucoma. Investig Ophthalmol Vis Sci. 2016;57(5):ORSFi1-6.

65. Gramlich OW, Brown AJ, Godwin CR, Chimenti MS, Boland LK, Ankrum JA, et al. Systemic mesenchymal stem cell treatment mitigates structural and functional retinal ganglion cell degeneration in a mouse model of multiple sclerosis. TransI Vis Sci Technol. 2020;9(8):16.

66. Connick P, Kolappan M, Crawley C, Webber DJ, Patani R, Michell AW, et al. Autologous mesenchymal stem cells for the treatment of secondary progressive multiple sclerosis: an open-label phase 2a proof-ofconcept study. Lancet Neurol. 2012;11(2):150-6.

67. Fu Y, Yan Y, Qi Y, Yang L, Li T, Zhang N, et al. Impact of autologous mesenchymal stem cell infusion on neuromyelitis optica spectrum disorder: a pilot, 2-year observational study. CNS Neurosci Ther. 2016;22(8):677-85.

68. Rhea EM, Logsdon AF, Banks WA, Erickson ME. Intranasal delivery: effects on the neuroimmune axes and treatment of neuroinflammation. Pharmaceutics. 2020;12(11):1120.

69. Tang Y, Han L, Bai X, Liang X, Zhao J, Huang F, et al. Intranasal delivery of bone arrow stromal cells preconditioned with fasudil to treat a mouse model of Parkinson's Disease. Neuropsychiatr Dis Treat. 2020;16:249-62.

70. Shen H, Gu X, Wei ZZ, Wu A, Liu X, Wei L. Combinatorial intranasal delivery of bone marrow mesenchymal stem cells and insulin-like growth factor-1 improves neurovascularization and functional outcomes following focal cerebral ischemia in mice. Exp Neurol. 2021;337:113542.

71. Larpthaveesarp A, Pathipati P, Ostrin S, Rajah A, Ferriero D, Gonzalez FF. Enhanced mesenchymal stromal cells or erythropoietin provide longterm functional benefit after neonatal stroke. Stroke. 2021;52(1):284-93.
72. Vaes JEG, van Kammen CM, Trayford C, van der Toorn A, Ruhwedel T, Benders $M$, et al. Intranasal mesenchymal stem cell therapy to boost myelination after encephalopathy of prematurity. Glia. 2021;69(3):655-80.

73. Harach T, Jammes F, Muller C, Duthilleul N, Cheatham V, Zufferey V, et al. Administrations of human adult ischemia-tolerant mesenchymal stem cells and factors reduce amyloid beta pathology in a mouse model of Alzheimer's disease. Neurobiol Aging. 2017;51:83-96.

74. Fransson M, Piras E, Wang H, Burman J, Duprez I, Harris RA, et al. Intranasal delivery of central nervous system-retargeted human mesenchymal stromal cells prolongs treatment efficacy of experimental autoimmune encephalomyelitis. Immunology. 2014;142(3):431-41.

75. Khan RS, Dine K, Bauman B, Lorentsen M, Lin L, Brown H, et al. Intranasa delivery of a novel amnion cell secretome prevents neuronal damage and preserves function in a mouse multiple sclerosis model. Sci Rep. 2017;7(1):41768.

76. Khan RS, Dine K, Wessel H, Brown L, Shindler KS. Effects of varying intranasal treatment regimens in ST266-mediated retinal ganglion cell neuroprotection. J Neuro-ophthalmol. 2019;39(2):191-9.

77. Khan RS, Ross AG, Willett K, Dine K, Banas R, Brown LR, et al. Amnionderived multipotent progenitor cells suppress experimental optic neuritis and myelitis. Neurother: J Am Soc Exp NeuroTher. 2020;18(1):448-59.

78. Steed DL, Trumpower C, Duffy D, Smith C, Marshall V, Rupp R, et al. Amnion-derived cellular cytokine solution: a physiological combination of cytokines for wound healing. Eplasty. 2008;8:e18-e.

79. Willett K, Khan RS, Dine K, Wessel H, Kirshner ZZ, Sauer JL, et al. Neuroprotection mediated by ST266 requires full complement of proteins secreted by amnion-derived multipotent progenitor cells. PLoS ONE. 2021;16(1):e0243862.

80. Grinblat GA, Khan RS, Dine K, Wessel H, Brown L, Shindler KS. RGC neuroprotection following optic nerve trauma mediated by intranasal delivery of amnion cell secretome. Investig Ophthalmol Vis Sci. 2018;59(6):2470-7.

81. Patel AA, Patel RJ, Patel SR. Nanomedicine for intranasal delivery to improve brain uptake. Curr Drug Deliv. 2018;15(4):461-9.

82. Estrada JC, Torres Y, Benguría A, Dopazo A, Roche E, Carrera-Quintanar $L$, et al. Human mesenchymal stem cell-replicative senescence and oxidative stress are closely linked to aneuploidy. Cell Death Dis. 2013;4(6):e691-e.

83. Røsland GV, Svendsen A, Torsvik A, Sobala E, McCormack E, Immervoll H et al. Long-term cultures of bone marrow-derived human mesenchymal stem cells frequently undergo spontaneous malignant transformation. Cancer Res. 2009;69(13):5331-9.

84. Moya A, Paquet J, Deschepper M, Larochette N, Oudina K, Denoeud $C$, et al. Human mesenchymal stem cell failure to adapt to glucose shortage and rapidly use intracellular energy reserves through glycolysis explains poor cell survival after implantation. Stem Cells. 2018;36(3):363-76

85. Yao Y, Huang J, Geng Y, Qian H, Wang F, Liu X, et al. Paracrine action of mesenchymal stem cells revealed by single cell gene profiling in infarcted murine hearts. PLoS ONE. 2015;10(6):e0129164.

86. Dai W, Hale SL, Kloner RA. Role of a paracrine action of mesenchymal stem cells in the improvement of left ventricular function after coronary artery occlusion in rats. Regen Med. 2007;2(1):63-8.

87. Gnecchi M, Zhang Z, Ni A, Dzau VJ. Paracrine mechanisms in adult stem cell signaling and therapy. Circ Res. 2008;103(11):1204-19.

88. Eleuteri S, Fierabracci A. Insights into the secretome of mesenchymal stem cells and its potential applications. Int J Mol Sci. 2019;20(18):4597.

89. Pitt JM, Kroemer G, Zitvogel L. Extracellular vesicles: masters of intercelIular communication and potential clinical interventions. J Clin Investig. 2016;126(4):1139-43.

90. Balbi C, Piccoli M, Barile L, Papait A, Armirotti A, Principi E, et al. First characterization of human amniotic fluid stem cell extracellular vesicles as a powerful paracrine tool endowed with regenerative potential. Stem Cells Transl Med. 2017;6(5):1340-55.

91. Johnstone RM, Mathew A Fau-Mason AB, Mason Ab Fau-Teng K, Teng K. Exosome formation during maturation of mammalian and avian reticulocytes: evidence that exosome release is a major route for externalization of obsolete membrane proteins. (0021-9541 (Print)). 
92. Azmi AS, Bao B, Sarkar FH. Exosomes in cancer development, metastasis, and drug resistance: a comprehensive review. Cancer Metastasis Rev. 2013;32(3-4):623-42.

93. Stoorvogel W, Kleijmeer MJ, Geuze HJ, Raposo G. The biogenesis and functions of exosomes. Traffic. 2002;3(5):321-30.

94. Théry C, Zitvogel L, Amigorena S. Exosomes: composition, biogenesis and function. Nat Rev Immunol. 2002;2(8):569-79.

95. Klingeborn M, Dismuke WM, Bowes Rickman C, Stamer WD. Roles of exosomes in the normal and diseased eye. Prog Retin Eye Res. 2017;59:158-77

96. Ludwig N, Hong CS, Ludwig S, Azambuja JH, Sharma P, Theodoraki MN, et al. Isolation and analysis of tumor-derived exosomes. Curr Protoc Immunol. 2019;127(1):e91.

97. Minciacchi VR, Freeman MR, Di Vizio D. Extracellular vesicles in cancer: exosomes, microvesicles and the emerging role of large oncosomes. Semin Cell Dev Biol. 2015;40:41-51.

98. Simpson RJ, Jensen SS, Lim JW. Proteomic profiling of exosomes: current perspectives. Proteomics. 2008;8(19):4083-99.

99. Svensson KJ, Christianson HC, Wittrup A, Bourseau-Guilmain E, Lindqvist E, Svensson LM, et al. Exosome uptake depends on ERK1/2-heat shock protein 27 signaling and lipid Raft-mediated endocytosis negatively regulated by caveolin-1. J Biol Chem. 2013;288(24):17713-24.

100. Valadi H, Ekström K, Bossios A, Sjöstrand M, Lee JJ, Lötvall JO. Exosomemediated transfer of mRNAs and microRNAs is a novel mechanism of genetic exchange between cells. Nat Cell Biol. 2007;9(6):654-9.

101. Jung JH, Fu X, Yang PC. Exosomes generated from iPSC-derivatives: new direction for stem cell therapy in human heart diseases. Circ Res. 2017;120(2):407-17.

102. Swanson WB, Gong T, Zhang Z, Eberle M, Niemann D, Dong R, et al. Controlled release of odontogenic exosomes from a biodegradable vehicle mediates dentinogenesis as a novel biomimetic pulp capping therapy. J Controlled Release: Off J Controlled Release Soc. 2020;324:679-94.

103. Mathew B, Torres LA, Gamboa Acha L, Tran S, Liu A, Patel R, et al. Uptake and distribution of administered bone marrow mesenchymal stem cell extracellular vesicles in retina. Cells. 2021;10(4):730. https://doi.org/10. 3390/cells10040730.

104. Mathew B, Ravindran S, Liu X, Torres L, Chennakesavalu M, Huang CC, et al. Mesenchymal stem cell-derived extracellular vesicles and retinal ischemia-reperfusion. Biomaterials. 2019;197:146-60.

105. Ochocinska MJ, Zlokovic BV, Searson PC, Crowder AT, Kraig RP, Ljubimova JY, et al. NIH workshop report on the trans-agency blood-brain interface workshop 2016: exploring key challenges and opportunities associated with the blood, brain and their interface. Fluids Barriers CNS. 2017;14(1):12

106. Zhuang X, Xiang X, Grizzle W, Sun D, Zhang S, Axtell RC, et al. Treatment of brain inflammatory diseases by delivering exosome encapsulated anti-inflammatory drugs from the nasal region to the brain. Mol Therapy: J Am Soc Gene Therapy. 2011;19(10):1769-79.

107. Wiklander OPB, Nordin JZ, O'Loughlin A, Gustafsson Y, Corso G, Mäger I, et al. Extracellular vesicle in vivo biodistribution is determined by cell source, route of administration and targeting. J Extracell Vesicles. 2015:4:26316

108. Yamashita T, Takahashi Y, Takakura Y. Possibility of exosome-based therapeutics and challenges in production of exosomes eligible for therapeutic application. Biol Pharm Bull. 2018;41(6):835-42.

109. Sharma P, Mesci P, Carromeu C, McClatchy DR, Schiapparelli L, Yates JR, et al. Exosomes regulate neurogenesis and circuit assembly. Proc Natl Acad Sci. 2019;116(32):16086.

110. Antonucci F, Turola E, Riganti L, Caleo M, Gabrielli M, Perrotta C, et al Microvesicles released from microglia stimulate synaptic activity via enhanced sphingolipid metabolism. EMBO J. 2012;31(5):1231-40.

111. Paolicelli RC, Bergamini G, Rajendran L. Cell-to-cell communication by extracellular vesicles: focus on microglia. Neuroscience. 2019;405:148-57.

112. Aggarwal S, Pittenger MF. Human mesenchymal stem cells modulate allogeneic immune cell responses. Blood. 2005;105(4):1815-22.

113. van den Akker F, Vrijsen KR, Deddens JC, Buikema JW, Mokry M, van Laake LW, et al. Suppression of T cells by mesenchymal and cardiac progenitor cells is partly mediated via extracellular vesicles. Heliyon. 2018;4(6):e00642
114. Ni H, Yang S, Siaw-Debrah F, Hu J, Wu K, He Z, et al. Exosomes derived from bone mesenchymal stem cells ameliorate early inflammatory responses following traumatic brain injury. Front Neurosci. 2019;13:14

115. Morrison TJ, Jackson MV, Cunningham EK, Kissenpfennig A, McAuley DF, O'Kane CM, et al. Mesenchymal stromal cells modulate macrophages in clinically relevant lung injury models by extracellular vesicle mitochondrial transfer. Am J Respir Crit Care Med. 2017;196(10):1275-86.

116. Arslan F, Lai RC, Smeets MB, Akeroyd L, Choo A, Aguor ENE, et al. Mesenchymal stem cell-derived exosomes increase ATP levels, decrease oxidative stress and activate PI3K/Akt pathway to enhance myocardial viability and prevent adverse remodeling after myocardial ischemia/ reperfusion injury. Stem Cell Res. 2013;10(3):301-12.

117. Dai YD, Sheng H, Dias P, Jubayer Rahman M, Bashratyan R, Regn D, et al. Autoimmune responses to exosomes and candidate antigens contribute to type 1 diabetes in non-obese diabetic mice. Curr Diab Rep. 2017;17(12):130.

118. Bakhti M, Winter C, Simons M. Inhibition of myelin membrane sheath formation by oligodendrocyte-derived exosome-like vesicles. J Biol Chem. 2011;286(1):787-96.

119. Buck AH, Coakley G, Simbari F, McSorley HJ, Quintana JF, Le Bihan T, et al. Exosomes secreted by nematode parasites transfer small RNAs to mammalian cells and modulate innate immunity. Nat Commun. 2014;5:5488.

120. Pegtel DM, Cosmopoulos K, Thorley-Lawson DA, van Eijndhoven MA, Hopmans ES, Lindenberg $J$, et al. Functional delivery of viral miRNAs via exosomes. Proc Natl Acad Sci U S A. 2010;107(14):6328-33.

121. Katakowski M, Buller B, Zheng X, Lu Y, Rogers T, Osobamiro O, et al. Exosomes from marrow stromal cells expressing miR-146b inhibit glioma growth. Cancer Lett. 2013;335(1):201-4.

122. Casella G, Colombo F, Finardi A, Descamps H, IIl-Raga G, Spinelli A, et al. Extracellular vesicles containing IL-4 modulate neuroinflammation in a mouse model of multiple sclerosis. Mol Therapy: J Am Soc Gene Therapy. 2018;26(9):2107-18.

123. Cone AS, Yuan X, Sun L, Duke LC, Vreones MP, Carrier AN, et al. Mesenchymal stem cell-derived extracellular vesicles ameliorate Alzheimer's disease-like phenotypes in a preclinical mouse model. Theranostics. 2021;11(17):8129-42.

124. Losurdo M, Pedrazzoli M, D'Agostino C, Elia CA, Massenzio F, Lonati E, et al. Intranasal delivery of mesenchymal stem cell-derived extracellular vesicles exerts immunomodulatory and neuroprotective effects in a 3xTg model of Alzheimer's disease. Stem Cells Transl Med. 2020;9(9):1068-84.

125. Kodali M, Castro OW, Kim DK, Thomas A, Shuai B, Attaluri S, et al. Intranasally administered human MSC-derived extracellular vesicles pervasively incorporate into neurons and microglia in both intact and status epilepticus injured forebrain. Int J Mol Sci. 2019;21(1):181.

126. Guo S, Perets N, Betzer O, Ben-Shaul S, Sheinin A, Michaelevski I, et al. Intranasal delivery of mesenchymal stem cell derived exosomes loaded with phosphatase and tensin Homolog siRNA Repairs complete spinal cord injury. ACS Nano. 2019;13(9):10015-28.

127. Haney MJ, Klyachko NL, Zhao Y, Gupta R, Plotnikova EG, He Z, et al. Exosomes as drug delivery vehicles for Parkinson's disease therapy. J Controlled Release: Off J Controlled Release Soc. 2015;207:18-30.

128. Long Q, Upadhya D, Hattiangady B, Kim D-K, An SY, Shuai B, et al. Intranasal MSC-derived A1-exosomes ease inflammation, and prevent abnormal neurogenesis and memory dysfunction after status epilepticus. Proc Natl Acad Sci. 2017;114(17):E3536-45.

129. Harrell CR, Fellabaum C, Arsenijevic A, Markovic BS, Djonov V, Volarevic $V$. Therapeutic potential of mesenchymal stem cells and their secretome in the treatment of glaucoma. Stem Cells Int. 2019;2019:7869130.

130. Mead B, Tomarev S. Bone marrow-derived mesenchymal stem cells-derived exosomes promote survival of retinal ganglion cells through miRNA-dependent mechanisms. Stem Cells Transl Med. 2017;6(4):1273-85.

131. Laso-García F, Ramos-Cejudo J, Carrillo-Salinas FJ, Otero-Ortega L Feliú A, Gómez-de Frutos M, et al. Therapeutic potential of extracellular vesicles derived from human mesenchymal stem cells in a model of progressive multiple sclerosis. PLoS ONE. 2018;13(9):e0202590.

132. Mokarizadeh A, Delirezh N, Morshedi A, Mosayebi G, Farshid A-A, Mardani K. Microvesicles derived from mesenchymal stem cells: 
potent organelles for induction of tolerogenic signaling. Immunol Lett. 2012;147(1):47-54.

133. Zhang K, Zhao X, Chen X, Wei Y, Du W, Wang Y, et al. Enhanced therapeutic effects of mesenchymal stem cell-derived exosomes with an injectable hydrogel for hindlimb ischemia treatment. ACS Appl Mater Interfaces. 2018;10(36):30081-91.

134. Bai L, Shao H, Wang H, Zhang Z, Su C, Dong L, et al. Effects of mesenchymal stem cell-derived exosomes on experimental autoimmune uveitis. Sci Rep. 2017;7(1):4323.

135. Bai L, Shao H, Wang H, Zhang Z, Su C, Dong L, et al. Author Correction: effects of mesenchymal stem cell-derived exosomes on experimental autoimmune uveitis. Sci Rep. 2018;8(1):9889.

136. Jaimes $Y$, Naaldijk Y, Wenk K, Leovsky C, Emmrich F. Mesenchymal stem cell-derived microvesicles modulate lipopolysaccharidesinduced inflammatory responses to microglia cells. Stem Cells. 2017;35(3):812-23.

137. Li JJ, Wang B, Kodali MC, Chen C, Kim E, Patters BJ, et al. In vivo evidence for the contribution of peripheral circulating inflammatory exosomes to neuroinflammation. J Neuroinflamm. 2018;15(1):8.

138. Riazifar M, Mohammadi MR, Pone EJ, Yeri A, Lässer C, Segaliny Al, et al. Stem cell-derived exosomes as nanotherapeutics for autoimmune and neurodegenerative disorders. ACS Nano. 2019;13(6):6670-88.

139. Yang Y, Ye Y, Su X, He J, Bai W, He X. MSCs-derived exosomes and neuroinflammation, neurogenesis and therapy of traumatic brain injury. Front Cell Neurosci. 2017;11:55.

140. Ponomarev ED, Veremeyko T, Weiner HL. MicroRNAs are universal regulators of differentiation, activation, and polarization of microglia and macrophages in normal and diseased CNS. Glia. 2013;61(1):91-103.

141. Melzer C, Rehn V, Yang Y, Bähre H, von der Ohe J, Hass R. Taxolloaded MSC-derived exosomes provide a therapeutic vehicle to target metastatic breast cancer and other carcinoma cells. Cancers. 2019;11(6):798.

142. Giunti D, Marini C, Parodi B, Usai C, Milanese M, Bonanno G, et al. Role of miRNAs shuttled by mesenchymal stem cell-derived small extracellular vesicles in modulating neuroinflammation. Sci Rep. 2021:11(1):1740.

143. Losurdo M, Pedrazzoli M, D'Agostino C, Elia CA, Massenzio F, Lonati E, et al. Intranasal delivery of mesenchymal stem cell-derived extracellular vesicles exerts immunomodulatory and neuroprotective effects in a 3xTg model of Alzheimer's disease. Stem Cell Trans Med. 2020;9(9):1068-84.

144. Clark K, Zhang S, Barthe S, Kumar P, Pivetti C, Kreutzberg N, et al. Placental mesenchymal stem cell-derived extracellular vesicles promote myelin regeneration in an animal model of multiple sclerosis. Cells. 2019:8(12):1497.

145. Kaminski N, Köster C, Mouloud Y, Börger V, Felderhoff-Müser U, Bendix I, et al. Mesenchymal stromal cell-derived extracellular vesicles reduce neuroinflammation, promote neural cell proliferation and improve oligodendrocyte maturation in neonatal hypoxic-ischemic brain injury. Front Cell Neurosci. 2020;14:601176.

146. Cudrici C, Niculescu T, Niculescu F, Shin ML, Rus H. Oligodendrocyte cell death in pathogenesis of multiple sclerosis: Protection of oligodendrocytes from apoptosis by complement. J Rehabil Res Dev. 2006:43(1):123-32.

147. Huang CC, Kang M, Shirazi S, Lu Y, Cooper LF, Gajendrareddy P, et al. 3D Encapsulation and tethering of functionally engineered extracellular vesicles to hydrogels. Acta Biomater. 2021;126:199-210.

148. Cui G-H, Guo H-D, Li H, Zhai Y, Gong Z-B, Wu J, et al. RVG-modified exosomes derived from mesenchymal stem cells rescue memory deficits by regulating inflammatory responses in a mouse model of Alzheimer's disease. Immunity Ageing. 2019;16(1):10.

149. Xin H, Li Y, Liu Z, Wang X, Shang X, Cui Y, et al. MiR-133b promotes neural plasticity and functional recovery after treatment of stroke with multipotent mesenchymal stromal cells in rats via transfer of exosomeenriched extracellular particles. Stem Cells. 2013;31(12):2737-46.

150. Seyedrazizadeh S-Z, Poosti S, Nazari A, Alikhani M, Shekari F, Pakdel F, et al. Extracellular vesicles derived from human ES-MSCs protect retinal ganglion cells and preserve retinal function in a rodent model of optic nerve injury. Stem Cell Res Ther. 2020;11(1):203.

151. Keller A, Leidinger $\mathrm{P}$, Lange J, Borries $\mathrm{A}$, Schroers $\mathrm{H}$, Scheffler $\mathrm{M}$, et al. Multiple sclerosis: microRNA expression profiles accurately differentiate patients with relapsing-remitting disease from healthy controls. PLoS ONE. 2009;4(10):e7440,

152. Duffy CP, McCoy CE. The role of MicroRNAs in repair processes in multiple sclerosis. Cells. 2020;9(7):1711.

153. Ma Q, Matsunaga A, Ho B, Oksenberg JR, Didonna A. Oligodendrocytespecific Argonaute profiling identifies microRNAs associated with experimental autoimmune encephalomyelitis. J Neuroinflammation. 2020;17(1):297.

154. Rhead B, Shao X, Graves JS, Chitnis T, Waldman AT, Lotze T, et al. miRNA contributions to pediatric-onset multiple sclerosis inferred from GWAS. Ann Clin Transl Neurol. 2019;6(6):1053-61.

155. Wang H, Moyano AL, Ma Z, Deng Y, Lin Y, Zhao C, et al. miR-219 Cooperates with miR-338 in myelination and promotes myelin repair in the CNS. Dev Cell. 2017:40(6):566-82.

156. Pusic AD, Kraig RP. Youth and environmental enrichment generate serum exosomes containing miR-219 that promote CNS myelination. Glia. 2014;62(2):284-99.

157. Zhang J, Li S, Li L, Li M, Guo C, Yao J, et al. Exosome and exosomal microRNA: trafficking, sorting, and function. Genom Proteomics Bioinform. 2015;13(1):17-24.

158. Maryam A, Mojdeh G, Abdolreza Naser M, Maryam I. Altered expression of miR-326 in T cell-derived exosomes of patients with relapsing-remitting multiple sclerosis. Iran J Allergy Asthma Immunol. 2019:18(1):108-13.

159. Kojima R, Bojar D, Rizzi G, Hamri GC, El-Baba MD, Saxena P, et al. Designer exosomes produced by implanted cells intracerebrally deliver therapeutic cargo for Parkinson's disease treatment. Nat Commun. 2018;9(1):1305.

160. Guo H, Ingolia NT, Weissman JS, Bartel DP. Mammalian microRNAs predominantly act to decrease target mRNA levels. Nature. 2010:466(7308):835-40.

161. Song M-S, Rossi JJ. Molecular mechanisms of Dicer: endonuclease and enzymatic activity. Biochem J. 2017:474(10):1603-18.

162. Theotoki El, Pantazopoulou VI, Georgiou S, Kakoulidis P, Filippa V, Stravopodis DJ, et al. Dicing the disease with Dicer: the implications of dicer ribonuclease in human pathologies. Int J Mol Sci. 2020;21(19):7223.

163. Thomou T, Mori MA, Dreyfuss JM, Konishi M, Sakaguchi M, Wolfrum C, et al. Adipose-derived circulating miRNAs regulate gene expression in other tissues. (1476-4687 (Electronic)).

164. Inamura N, Go S, Watanabe T, Takase H, Takakura N, Nakayama A, et al. Reduction in miR-219 expression underlies cellular pathogenesis of oligodendrocytes in a mouse model of Krabbe disease. Brain Pathol (Zur, Switz). 2021;31:e12951.

165. Marangon D, Boda E, Parolisi R, Negri C, Giorgi C, Montarolo F, et al. In vivo silencing of miR-125a-3p promotes myelin repair in models of white matter demyelination. Glia. 2020;68(10):2001-14.

166. Tripathi A, Volsko C, Garcia JP, Agirre E, Allan KC, Tesar PJ, et al. Oligodendrocytei ntrinsic miR-27a controls myelination and remyelination. Cell Rep. 2019:29(4):904-19.e9.

167. Alvarez-Erviti L, Seow Y, Yin H, Betts C, Lakhal S, Wood MJ. Delivery of siRNA to the mouse brain by systemic injection of targeted exosomes. Nat Biotechnol. 2011;29(4):341-5.

168. Guo L, Huang Z, Huang L, Liang J, Wang P, Zhao L, et al. Surface-modified engineered exosomes attenuated cerebral ischemia/reperfusion injury by targeting the delivery of quercetin towards impaired neurons. J Nanobiotechnol. 2021;19(1):141.

169. Kim G, Kim M, Lee Y, Byun JW, Hwang DW, Lee M. Systemic delivery of microRNA-21 antisense oligonucleotides to the brain using T7-peptide decorated exosomes. J Controlled Release: Off J Controlled Release Soc. 2020;317:273-81.

170. Hosseini Shamili F, Alibolandi M, Rafatpanah H, Abnous K, Mahmoudi $\mathrm{M}$, Kalantari M, et al. Immunomodulatory properties of MSC-derived exosomes armed with high affinity aptamer toward mylein as a platform for reducing multiple sclerosis clinical score. J Controlled Release: Off J Controlled Release Soc. 2019;299:149-64.

171. Li K, Rodosthenous RS, Kashanchi F, Gingeras T, Gould SJ, Kuo LS, et al. Advances, challenges, and opportunities in extracellular RNA biology: insights from the NIH exRNA Strategic Workshop. JCl insight. 2018;3(7):e98942.

172. Stranford DM, Leonard JN. Delivery of biomolecules via extracellular vesicles: a budding therapeutic strategy. Adv Genet. 2017;98:155-75. 
173. Huang CC, Kang M, Lu Y, Shirazi S, Diaz JI, Cooper LF, et al. Functionally engineered extracellular vesicles improve bone regeneration. Acta Biomater. 2020;109:182-94.

174. Baldari S, Di Rocco G, Magenta A, Picozza M, Toietta G. Extracellular vesicles-encapsulated MicroRNA-125b produced in genetically modified mesenchymal stromal cells inhibits hepatocellular carcinoma cell proliferation. Cells. 2019;8(12):1560.

175. Villarroya-Beltri C, Gutiérrez-Vázquez C, Sánchez-Cabo F, Pérez-Hernández D, Vázquez J, Martin-Cofreces N, et al. Sumoylated hnRNPA2B1 controls the sorting of miRNAs into exosomes through binding to specific motifs. Nat Commun. 2013;4(1):2980.

176. Fan B, Chopp M, Zhang ZG, Liu XS. Treatment of diabetic peripheral neuropathy with engineered mesenchymal stromal cell-derived exosomes enriched with microRNA-146a provide amplified therapeutic efficacy. Exp Neurol. 2021;341:113694.

177. Xin H, Liu Z, Buller B, Li Y, Golembieski W, Gan X, et al. MiR-17-92 enriched exosomes derived from multipotent mesenchymal stromal cells enhance axon-myelin remodeling and motor electrophysiological recovery after stroke. J Cereb Blood Flow Metab. 2021;41(5):1131-44.

178. Osorio-Querejeta I, Carregal-Romero S, Ayerdi-Izquierdo A, Mäger I, Nash LA, Wood M, et al. MiR-219a-5p enriched extracellular vesicles induce OPC differentiation and EAE improvement more efficiently than liposomes and polymeric nanoparticles. Pharmaceutics. 2020;12(2):186.

179. Li Y, Fan L, Liu S, Liu W, Zhang H, Zhou T, et al. The promotion of bone regeneration through positive regulation of angiogenic-osteogenic coupling using microRNA-26a. Biomaterials. 2013;34(21):5048-58.

180. Liu X, Yang Y, Li Y, Niu X, Zhao B, Wang Y, et al. Integration of stem cell-derived exosomes with in situ hydrogel glue as a promising tissue patch for articular cartilage regeneration. Nanoscale. 2017;9(13):4430-8

181. Wang C, Wang M, Xu T, Zhang X, Lin C, Gao W, et al. Engineering bioactive self-healing antibacterial exosomes hydrogel for promoting chronic diabetic wound healing and complete skin regeneration. Theranostics. 2019:9(1):65-76

182. Han C, Zhou J, Liu B, Liang C, Pan X, Zhang Y, et al. Delivery of miR-675 by stem cell-derived exosomes encapsulated in silk fibroin hydrogel prevents aging-induced vascular dysfunction in mouse hindlimb. Mater Sci Eng C. 2019;99:322-32.
183. Shi Q, Qian Z, Liu D, Sun J, Wang X, Liu H, et al. GMSC-derived exosomes combined with a chitosan/silk hydrogel sponge accelerates wound healing in a diabetic rat skin defect model. Front Physiol. 2017:8:904

184. Park SS, Caballero S, Bauer G, Shibata B, Roth A, Fitzgerald PG, et al. Long-term effects of intravitreal injection of GMP-grade bone-marrowderived CD34+ cells in NOD-SCID mice with acute ischemia-reperfusion injury. Investig Ophthalmol Vis Sci. 2012;53(2):986-94.

185. Yazdanyar A, Zhang P, Dolf C, Smit-McBride Z, Cary W, Nolta JA, et al. Effects of intravitreal injection of human CD34(+) bone marrow stem cells in a murine model of diabetic retinopathy. Exp Eye Res. 2020;190:107865.

186. Herman S, Fishel I, Offen D. Intranasal delivery of mesenchymal stem cells-derived extracellular vesicles for the treatment of neurological diseases. Stem Cells. 2021. https://doi.org/10.1002/stem.3456.

187. Linares R, Tan S, Gounou C, Arraud N, Brisson AR. High-speed centrifugation induces aggregation of extracellular vesicles. J Extracell Vesicles. 2015;4:29509.

188. Chinnadurai R, Copland IB, Ng S, Garcia M, Prasad M, Arafat D, et al. Mesenchymal stromal cells derived from Crohn's patients deploy indoleamine 2,3-dioxygenase-mediated immune suppression, independent of autophagy. Mol Therapy: J Am Soc Gene Therapy. 2015;23(7):1248-61.

189. Yin JQ, Zhu J, Ankrum JA. Manufacturing of primed mesenchymal stromal cells for therapy. Nat Biomed Eng. 2019;3(2):90-104.

190. Butreddy A, Kommineni N, Dudhipala N. Exosomes as naturally occurring vehicles for delivery of biopharmaceuticals: insights from drug delivery to clinical perspectives. Nanomaterials (Basel). 2021;11(6):1481.

191. Patel DB, Santoro M, Born LJ, Fisher JP, Jay SM. Towards rationally designed biomanufacturing of therapeutic extracellular vesicles: impact of the bioproduction microenvironment. Biotechnol Adv. 2018;36(8):2051-9.

192. Whitford W, Guterstam P. Exosome manufacturing status. Future Med Chem. 2019;11(10):1225-36.

\section{Publisher's Note}

Springer Nature remains neutral with regard to jurisdictional claims in published maps and institutional affiliations.
Ready to submit your research? Choose BMC and benefit from:

- fast, convenient online submission

- thorough peer review by experienced researchers in your field

- rapid publication on acceptance

- support for research data, including large and complex data types

- gold Open Access which fosters wider collaboration and increased citations

- maximum visibility for your research: over $100 \mathrm{M}$ website views per year

At BMC, research is always in progress.

Learn more biomedcentral.com/submissions 